\title{
Evaluation of Nutritional Status, Food Intake and Costs of Food Waste in Hospitalized Patients, Considering Relevant Causes and Finding Possible Solutions: Protocol of a Mixed-Method Study
}

\author{
Razieh Anari ${ }^{1}$, Maryam Amini ${ }^{1}$, Bahareh Nikooyeh ${ }^{1}$, Delaram Ghodsi ${ }^{1}$, Parisa Torabi ${ }^{2}$, Tirang R. Neyestani ${ }^{1, *}$ \\ 1 Department of Nutrition Research, Faculty of Nutrition Sciences and Food Technology, National Nutrition and Food Technology Research Institute, Shahid \\ Beheshti University of Medical Sciences, Tehran, Iran \\ 2 Community Nutrition Office, Iran Ministry of Health and Medical Education, Tehran, Iran
}

\begin{abstract}
A B S T R A C T
Hospitalization may affect patients' nutritional status due to the altered food intake. In addition to their health consequences, plate food waste includes several economic and environmental costs for the governments and societies. Therefore, the aim of the present investigation is primarily to assess the nutritional status of the patients hospitalized in general wards and secondly to evaluate the quantity and financial burden of the patients' food waste along with their possible nutritional outcomes. A mixedmethod study is carried out in medical and surgical wards of general hospitals in Tehran with eligible adult inpatients. Anthropometric, demographic and dietary intake data are collected. Patients' plate food waste in breakfast, lunch, and snacks within a day are weighed. The economic costs of food waste are calculated. Additionally, nutritional status is determined through 1) subjective assessment tools for malnutrition (MNA and SGA); 2) serum albumin, pre-albumin and total protein (protein status); 3) serum retinol and 25-hydroxycalciferol (micronutrient status); and 4) serum $\beta$-carotene, total antioxidant capacity, malondialdehyde and highly sensitive C-reactive protein (inflammatory status). Moreover, a qualitative study evaluates the possible reasons for wasting foods. This study provides appropriate data regarding the health and economic burden of food waste in the studied hospitals to healthcare authorities and policymakers for planning to decrease food waste and to improve patients' nutritional status.
\end{abstract}

Keywords: Economic burden, Food waste, hospital, Malnutrition, Nutrition, Nutritional status, Qualitative study, Study protocol

\section{Introduction}

Hospitalized patients are mostly (67-94\%) dependent on the hospital's food to supply their nutritional requirements $(1,2)$. Patients with insufficient food intake are more susceptible to nutritional deficiency (3), which is prevalently observed in hospitalized patients (4) and can cause or exacerbate malnutrition $(5,6)$. Studies have reported that a noticeable proportion of the hospitalized patients $(\sim 40 \%)$ suffer from malnutrition globally, including both developed $(20-46 \%)$ and developing countries $(\sim 50 \%)(4,7,8)$. For instance, a recent Canadian prospective cohort revealed that around $40 \%$ of admitted patients had some sort of malnutrition and longer hospital stays (9). This figure was between 30 and $63.1 \%$ in Iranian hospitals (10-12). Moreover, a comprehensive study in 20 general Iranian hospitals revealed that almost one out of four patients suffered from malnutrition (13). Undernutrition can also influence medical treatment and recovery from the disease $(4,14)$, risk of infections (15) and even risk of death $(6,16)$. Malnourished patients also have longer hospital stay and greater likelihood of readmission $(16,17)$, which could increase hospital costs up to $308.9 \%$ (17).

Adequate nutrition is associated with a better clinical outcome in hospitalized patients (18). However, approximately $30 \%$ of the patients' food remains intact during hospitalization (4). This measure varies from country to country. For example, a study in Portugal demonstrated that, on average, $35 \%$ of served food (equaled to $953 \mathrm{~g}$ ) is wasted by patients everyday (19). Investigations in UK hospitals also showed that patients leave $14 \%$ of their meals during three consecutive days (20) and as high as $40 \%$ of served food over 28 days (21). Based on previous studies in Iranian hospitals, the food waste ranges from 14 to $47 \%$ of total wasted materials in hospitals $(12,22-24)$. On the other hand, wasted foods may have some adverse environmental impacts by emitting $\mathrm{CO}_{2}$. The European Union estimates an average emission of at least 1.9 tons of $\mathrm{CO}_{2}$ per ton of wasted food arising 
from both the food chain (e.g., production, processing, transportation, storage and preparation) and after wasting processes (25), leading to exacerbation of global warming (26).Besides clinical and environmental aspects, food waste is also important regarding economic impacts on governments and health systems (27). The approximate cost of prepared food in hospitals is at least EUR 2 (28), depending on country and culinary factors such as culture. For instance, food waste annually contributes to EUR 35.5 million of health expenses in Portuguese hospitals (19) and GBP 139,655 in UK hospitals (21).

Many factors, including malnutrition, disease, food delivery system, food palatability or its quality, can alter patients' food intake. A study in Tehran reported that only $27 \%$ of the hospitalized patients were satisfied with their food (29), which could exacerbate food waste. The reasons for incomplete food intake and resulting food waste are not necessarily similar among different patients and wards. Previous studies reported the highest amount of food waste in medical, gastroenterology and surgical wards $(10,19)$. Thus, the underlying factors for food waste should be precisely and locally identified. In spite of the importance and extent of food waste, there is a lack of sufficient data regarding clinical and economical dimensions of food

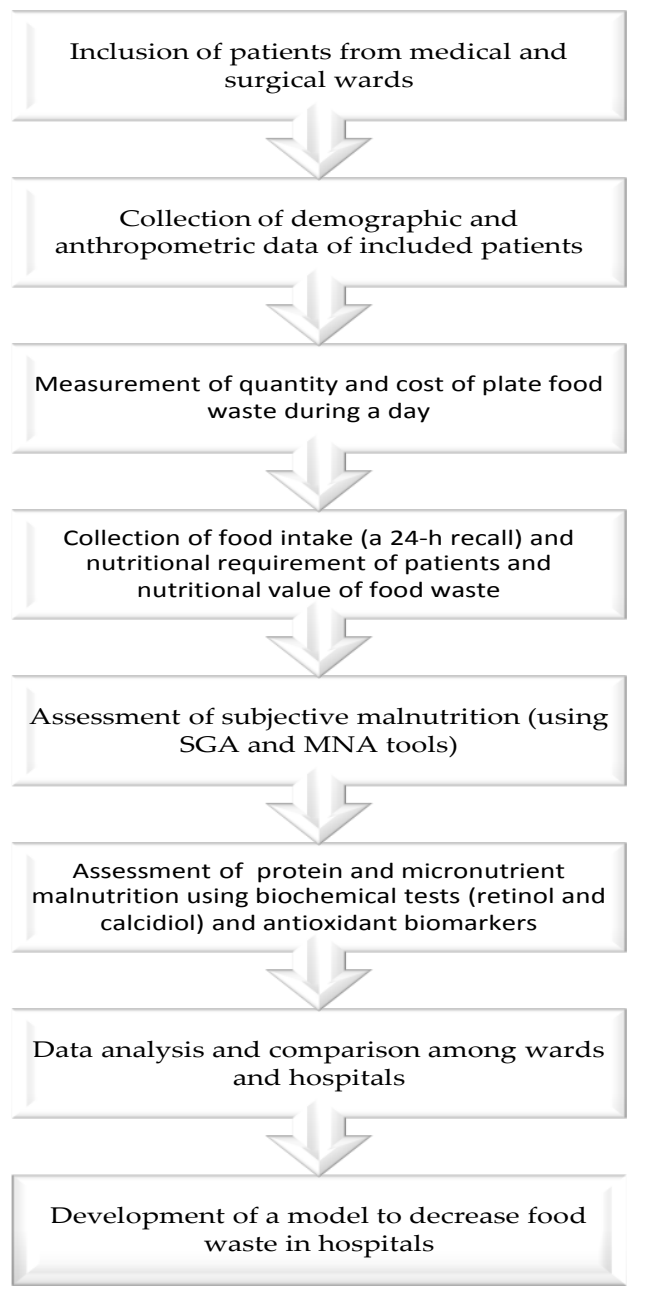

waste in Iranian hospitals. Therefore, this study aims to assess the nutritional status of patients hospitalized in medical and surgical wards of three general hospitals in Tehran and also to determine the quantity and cost of food waste in those hospitals. Meanwhile, the main causes of food waste by patients will be investigated using a qualitative study to find the appropriate solutions to reduce it.

\section{Materials and Methods}

Study design: A mixed-method study is carried out in medical and surgical wards of three general hospitals in Tehran, Iran, including Shohada-ye-Tajrish, Shahid Modarres and Emam-Hossein, all belonging to Shahid Beheshti University of Medical Sciences, Tehran, Iran. This study aims: (i) to assess malnutrition and nutritional intake of patients, (ii) to measure plate food waste and estimate its cost, and (iii) to identify the reasons for wasting foods by patients (Figure 1).

Calculation of sample size: Considering the effect size of 0.25 (30), type 1 error of $5 \%$ and the power of $90 \%$, the sample size will be 171 patients using $G^{*}$ Power software (31).

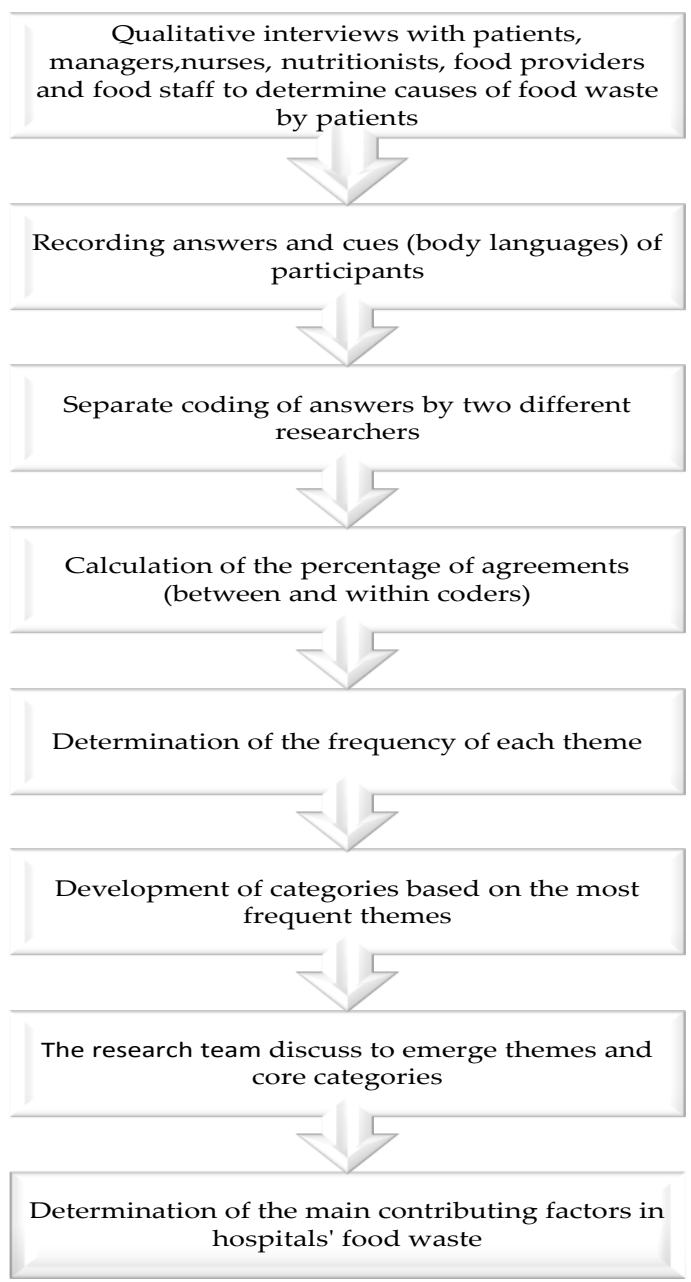

Figure 1. A summary of the steps for fulfilling the study aims 
Participants: We will consequently enroll adult inpatients hospitalized in medical and surgical wards of three general hospitals in the study until fulfillment of the sample size. The following general criteria will be used for enrolment:

Inclusion criteria: Hospitalization in medical or surgical ward, age $\geq 19$ years, consumption of hospital food, i.e. food prepared in hospital's kitchen and distributed by serving staff, and patient's satisfaction to participate in the study.

Non-inclusion criteria: Pregnancy, unconsciousness or inability to eat by themselves.

Exclusion criteria: Diet transition to liquid or soft diet, enteral or parenteral feeding or NPO (nil per oral), transferring to another ward (except medical and surgical) or intensive care unit (ICU), discharge from hospital or death, lack of plate return to the kitchen for any reason.

Ethical considerations: The Ethics Committee of National Nutrition and Food Technology Research Institute (NNFTRI) has approved the study protocol (ethical code: IR.SBMU.NNFTRI.REC.1398.073; approval date: 202001-05). Due to the observational nature of the study, we will implement no intervention and only current malnutrition status, food intake and reasons to waste food will be assessed. Before initiation of the study, patients will declare their consent to enter the study through signing a written testimonial. This study is organized based on the STROBE guidelines to ensure the quality of reporting (32).

Data collection and variables: This is a mixed-method study and includes both quantitative and qualitative approaches.

\section{a. Quantitative examination}

Demographic data: A socio-demographic questionnaire, including age, sex, education, marital status, cause of hospitalization, disease history, length of hospital stay, smoking status and current use of drugs and supplements are completed for each participant.

Anthropometric measures: A trained nutritionist will collect anthropometric measurements. Patients' weights will be measured using a calibrated digital scale with the accuracy of $100 \mathrm{~g}$ (Seca, model 840, Maximum: $140 \mathrm{~kg}$, Hamburg, Germany). In case of movement restriction (due to heavy surgeries, fractions, paralysis, etc.), weights will be recorded as self-reported by the patient. For patients with edema, the physician will determine the weight. Heights will be measured in standing position with minimal clothing and the accuracy of $0.1 \mathrm{~cm}$ (Seca, Hamburg, Germany). If direct measurement is not feasible because of the patient's condition, indirect methods will be applied to estimate height, either using ulna length (33) or preferably using knee height by a non-flexible tape measure $(34,35)$. To estimate height using ulna length, the distance between the point of elbow (olecranon process) and the midpoint of prominent bone of the wrist (styloid process), possibly from the left side, will be measured and rounded to the nearest $0.5 \mathrm{~cm}$ and height will be estimated using the standard method (33). Knee height will also be measured in supine lying position using a tape measure, by holding both knee and ankle at 90-degree angles $(34,35)$, and height will be calculated using the following formulas:

Heights for males $(\mathbf{c m}): 64.19-(0.04 \times$ age $)+(2.02 \times$ knee height $)$

Heights for females $(\mathbf{c m}): 84.88-(0.24 \times$ age $)+(1.83 \times$ knee height $)$

Quantity of plate food waste: Food waste will be measured during two main meals (breakfast and lunch) and snacks (in the morning and evening). Food ingredients will be extracted from the hospital's food guide and validated by asking the chef or food preparing staff. A trained nutritionist will record the average portion size by weighing at least two sample dishes in each meal using a portable digital scale with the accuracy of $1 \mathrm{~g}$. To enhance our visual understanding of meals and snacks, some pictures will be taken of foods/snacks being served at kitchen. Foods served in trays, dishes or disposable containers will be distributed among the due wards, i.e., medical and surgical wards, through the hospital's food delivery system and leftovers will be returned to the weighing zone. Then, total amount of plate food waste will be measured and calculated per studied patient, meal (breakfast, lunch, snacks) and ward as the following:

$\mathrm{WP}=\frac{1}{\mathrm{n}}\left(\sum_{i=1}^{n} \frac{\sum_{j=1}^{3} \mathrm{WF}_{i j}}{\sum_{j=1}^{3} \mathrm{FP}_{i j}}\right) \times 100$

WP: percent of daily wasted food per patient

n: total number of the studied patients

i: refers to the specific daily measurement for each patient WF: weight of daily wasted food for each patient in each meal (gr)

FP: average weight of the food portion in each meal on the day of measurement (gr)

j: refers to the specific meal including $1=$ breakfast, $2=$ snacks and $3=$ lunch

$$
\mathbf{W M}=\frac{1}{n}\left(\sum_{i=1}^{n} \frac{\mathrm{WF}_{i j}}{\mathrm{FP} i j}\right) \times 100, \mathrm{j}=1,2,3
$$

WM: percent of daily wasted food per meal

$$
\mathbf{W W}=\frac{1}{d}\left[\sum_{i=1}^{d}\left(\mathrm{WP} \times \mathrm{n}_{d}\right)\right] \times 100
$$

WW: percent of daily wasted food per ward $\mathbf{n}_{\mathbf{d}}$ : total number of eligible patients in each ward on the day of measurement

d: total number of measurement days.

Cost of food waste: A nutritionist will collect information on food ingredients by asking the chef. After measuring the 
portion size, the total price of a typical portion will be estimated by asking the food provider who routinely purchases raw materials for the kitchen. This will not include procedure expenses, such as energy or employees' salaries. Cost of food waste will be calculated and reported per studied patient, meal (breakfast, lunch, snacks) and ward using the following equations:

$$
\begin{aligned}
& \mathbf{C W P}=\mathrm{WP} \times \mathrm{TCM} \\
& \mathbf{T C M}=\frac{1}{\mathrm{~d}} \sum_{k=1}^{d}\left(\sum_{j=1}^{3} \mathrm{CM}_{\mathrm{kj}}\right), \mathrm{j}=1,2,3
\end{aligned}
$$

CWP: cost of wasted food per patient on the day of measurement (Rial)

TCM: average total cost of all meals in a day (Rial)

CM: cost of food portion in each meal on the day of measurement (Rial)

k: day of measurement.

$$
\begin{aligned}
& \mathbf{C W M}=\mathrm{WM}_{\mathrm{j}} \times \mathrm{CEM}_{\mathrm{j}}, \mathrm{j}=1,2,3 \\
& \mathbf{C E M}=\frac{1}{\mathrm{~d}}\left(\sum_{k=1}^{d} \mathrm{CM}_{\mathrm{kj}}\right), \mathrm{j}=1,2,3
\end{aligned}
$$

CWM: cost of wasted food per meal on the day of measurement (Rial)

CEM: average cost of each meal in a day (Rial)

\section{$\mathbf{C W W}=\mathrm{CWP} \times \mathrm{N}$}

CWW: cost of daily wasted food per ward (Rial)

$\mathbf{N}$ : average daily number of eligible patients in each ward during the study period.
All costs of food waste will be reported in the national currency and will be finally converted to US dollars using the average exchange rate during the study period.

Nutritional value of wasted food: The amount of wasted food will be entered into Nutritionist IV software (First Data Bank Inc., San Bruno, CA, USA, 1997) to extract energy, protein and micronutrient content (vitamin A and D) of wasted food for each patient.

Nutritional intake and requirement: The mean daily energy and protein intakes will be extracted from a 24-h food recall using Nutritionist IV software (First Data Bank Inc., San Bruno, CA, 1997) modified for Iranian food ingredients. The mean daily energy and protein intake will be reported for medical and surgical wards of studied hospitals. Resting metabolic rate (RMR) will be calculated for each patient according to age, weight and sex using an equation developed for Iranians for patients 19-59 years old (36) or the Mifflin equation for those $\geq 60$ years old (37) (Table 1). Finally, total energy expenditure (TEE) will be calculated considering injury factors (IF) and activity

\begin{tabular}{|c|c|}
\hline Iranians equation $^{(36)}$ & Mifflin equation $^{(37)}$ \\
\hline $\begin{array}{l}\text { Males }(18-30 \mathrm{yrs}):(8.4 \times \mathrm{Ht} \text { in } \mathrm{cm})+(5 \times \mathrm{wt} \text { in } \mathrm{kg})+(27.5 \times \text { age in } \mathrm{yrs}) \\
-869.7\end{array}$ & Males $(\geq 60$ years $): 10(w t)+6.25(\mathrm{Ht})-5($ age $)+5$ \\
\hline $\begin{array}{l}\text { Males }(31-60 \mathrm{yrs}):(7.8 \times \mathrm{Ht} \text { in } \mathrm{cm})+(12.5 \times \mathrm{wt} \text { in } \mathrm{kg})-(5.64 \times \text { age in } \\
\text { yrs })-349.9\end{array}$ & Females $(\geq 60$ years $): 10(\mathrm{wt})+6.25(\mathrm{Ht})-5(\mathrm{age})-161$ \\
\hline \multicolumn{2}{|l|}{$\begin{array}{l}\text { Females }(18-30 \mathrm{yrs}):(8.4 \times \mathrm{Ht} \text { in } \mathrm{cm})+(5 \times \text { wt in } \mathrm{kg})+(27.5 \times \text { age in } \\
\mathrm{yrs})-979.7\end{array}$} \\
\hline $\begin{array}{l}\text { Females }(31-60 \mathrm{yrs}):(7.8 \times \mathrm{Ht} \text { in } \mathrm{cm})+(12.5 \times \text { wt in } \mathrm{kg})-(5.64 \times \text { age in } \\
\text { yrs })-455.4\end{array}$ & \\
\hline
\end{tabular}
factors (AF) (38) (Table 2) as:

$$
\text { TEE }=\mathrm{RMR} \times \mathrm{IF} \times \mathrm{AF}
$$

Table 1. Estimation of the resting metabolic rates (kcal/d)

Table 2. Injury and activity factors

\begin{tabular}{llll|}
\hline Condition & IF & Condition & AF \\
\hline Minor surgery & $1.0-1.1$ & Confined to bed & 1.2 \\
Major surgery & $1.1-1.3$ & Ambulatory, low activity & 1.3 \\
Mild infection & $1.0-1.2$ & Average activity & $1.5-1.75$ \\
Moderate infection & $1.2-1.4$ & Highly active & 2.0 \\
Severe infection & $1.4-1.8$ & & \\
Skeletal or blunt trauma & $1.2-1.4$ & & \\
Skeletal or head trauma (steroid treated) & $1.6-1.8$ & & \\
Burns involving $\leq 20 \%$ BSA & $1.2-1.5$ & & \\
Burns involving 20-40\% BSA & $1.5-1.8$ & & \\
Burns involving $>40 \%$ BSA & $1.8-2.0$ & & \\
\hline$A F:$ activity factor; $B S A$ : body surface area; $I F:$ Injury factor; Based on Long et al. 1984(38)
\end{tabular}


Malnutrition assessment: Subjective and objective malnutrition are assessed for each eligible patient as the following:

I. Subjective malnutrition: Subjective malnutrition will be evaluated using subjective tools: subjective global assessment (SGA) tool for adults 19-65 years old (39) and mini-nutritional assessment (MNA) tool for adults $\geq 65$ years old (40).

II. Objective malnutrition: Protein malnutrition will be evaluated by measuring serum albumin, prealbumin $(\mathrm{PAB})$ and total protein using standard methods. If the concentrations of all three serum proteins are low, this will signify protein malnutrition (41). Micronutrient malnutrition will be measured by assessing vitamins A and D status using serum retinol and 25-hydroxycalciferol [25(OH)D] determination, respectively.

\section{Biochemical analyses}

Blood sample preparation: The day after measuring food waste, a $10-\mathrm{mL}$ venous blood sample will be drawn from patients. The samples will be immediately sent to the Laboratory of Nutrition Research, NNFTRI, in a cold box and sera will be separated by centrifuging at $800 \times g$ for 20 min at room temperature and will be stored at $-70{ }^{\circ} \mathrm{C}$ until the day of biochemical examination.

The following biochemical tests will be employed to assess the status of the selected micronutrient (vitamins A and $\mathrm{D}$ ), protein malnutrition (albumin, PAB and total protein), anti-oxidative defense (total antioxidant capacity (TAC), malondialdehyde (MDA) and $\beta$-Carotene) and inflammatory status of the patients (highly sensitive $\mathrm{C}$ reactive protein (hs-CRP)):

Serum retinol: To assess vitamin A status, serum retinol will be measured using high-performance liquid chromatography (HPLC) as originally described (42) with some minor modifications (43). In this study, serum concentrations $0.35-0.70 \mu \mathrm{mol} / \mathrm{L}(10-20 \mu \mathrm{g} / \mathrm{dL})$ will be considered as marginal vitamin A deficiency, $<0.35 \mu \mathrm{mol} / \mathrm{L}$ $(10 \mu \mathrm{g} / \mathrm{dL})$ as vitamin A deficiency, $>1.05 \mu \mathrm{mol} / \mathrm{L}(30$ $\mu \mathrm{g} / \mathrm{dL})$ as adequate status and $>3.49 \mu \mathrm{mol} / \mathrm{L}(100 \mu \mathrm{g} / \mathrm{dL})$ as hypervitaminosis A (44-46).

Serum $\beta$-Carotene: Serum concentrations of $\beta$-carotene will be assayed using HPLC (47). In fact, serum retinol and $\beta$-carotene will be determined simultaneously.

Serum 25(OH)D: Vitamin D status will be determined by measuring circulating $25(\mathrm{OH}) \mathrm{D}$ concentrations using the enzyme immunoassay (EIA) method (Padtan Gostar Isar ${ }^{\circledR}$, Tehran, Iran). In this study, serum 25(OH)D concentrations $>50 \mathrm{nmol}(20 \mathrm{ng} / \mathrm{mL})$ will be considered as sufficiency, $27.5-50 \mathrm{nmol}(11-20 \mathrm{ng} / \mathrm{mL})$ as insufficiency and $<27.5$ noml $/ \mathrm{L}(11 \mathrm{ng} / \mathrm{mL})$ as deficiency (48).

Serum MDA: Serum MDA, as a biomarker of oxidative stress, will be assessed by measuring thiobarbituric acid reactive substances (TBARS), as described elsewhere (49, $50)$.

Serum TAC: TAC will be evaluated using 2,2-azinobis (3ethylbenzothiazoline-6-sulfonate) (ABTS) reagent and bovine serum albumin as standard (51).

Serum hs-CRP: It will be measured using EIA (Pars Azmoon, Tehran, Iran). In this study, serum hs-CRP will be interpreted as follows (52): $<3.0 \mathrm{mg} / \mathrm{L}$ : normal; $3-10$ $\mathrm{mg} / \mathrm{L}$ : minor elevation; 10 to $100 \mathrm{mg} / \mathrm{L}$ : moderate elevation; >100 mg/L: marked elevation; and $>500 \mathrm{mg} / \mathrm{L}$ : severe elevation.

Serum albumin: We will measure serum albumin using the specific commercial kit (Pars Azmun, Iran). Concentrations $3.5-5.0 \mathrm{~g} / \mathrm{dL}$ will be considered normal (53).

Serum PAB: Serum pre-albumin will be measured through the turbidimetric immunoassay method using commercial kit (Zellbio, Germany). Concentrations between 15 and 35 $\mathrm{mg} / \mathrm{dL}$ will be considered normal (54).

Serum total protein: Serum total protein will be measured using a specific commercial kit (Pars Azmun, Iran). The normal range for total protein is between 6.0 and $8.4 \mathrm{~g} / \mathrm{dL}$ (53).

Statistical analyses: Quantitative and qualitative data regarding food waste and nutritional status will be analyzed using SPSS software (version 21, SPSS Inc., Chicago, IL, USA). Quantitative variables such as amount and cost of food waste will be reported as mean \pm standard deviation (SD), and qualitative variables, such as malnutrition status or micronutrient deficiency, will be expressed as percent or proportion. Shapiro-Wilk test will be used for evaluating the normality of data distribution. Biochemical results, food intake (energy and micronutrients), food waste and its cost will be compared among different malnutrition categories, wards and hospitals using one-way analysis of variance (ANOVA) or the equivalent non-parametric test, considering gender and age as the confounding factors. Finally, data analysis by linear logistic regression will provide a model using the studied variables. $p$-values less than 0.05 will be considered as significant in all statistical tests.

\section{b. Qualitative study}

Participants: To collect data regarding possible reasons for wasting food, we will conduct a qualitative study with nurses, nutritionists, food staff (i.e., chef, chef assistant and delivery staff), food providers, hospital managers and patients hospitalized in medical and surgical wards of the studied hospitals.

Methods: The qualitative study includes several individual "in-depth" interviews. The interviews will be guided by a "Topic Guide" (Table 3). 
Razieh Anari, et al: Nutritional status, food intake and costs of food waste

Table 3. Topic guides for various target groups

\begin{tabular}{ll}
\hline $\begin{array}{l}\text { Participants' subgroup } \\
\text { (interviewee) }\end{array}$ & Question \\
\hline Nurses & 1. $\quad$ What is your opinion about the quality of served foods/ snacks for patients in this hospital? \\
2. $\quad$ What is your opinion about the quantity of served foods/ snacks for patients in this hospital? \\
3. In your opinion which parts of the foods have not been eaten (meat/chicken/fish, bread, rice, \\
4. $\quad$ Do you think to which extent the hospital's food is in accordance with patients' requirements \\
a. In your opinion, for what reasons incomplete consumption of foods by patients exists? \\
6. What is your recommendation for the patients to completely consume their foods?
\end{tabular}

\begin{tabular}{|c|c|}
\hline Nutritionists & $\begin{array}{l}\text { 1. What is your opinion about the quality and quantity of served foods/ snacks for patients in this } \\
\text { 2. In your opinion which parts of the foods have not been eaten (meat/chicken/fish, bread, rice, } \\
\text { vegetables, dairy, fruits) by patients in this hospital? And why? } \\
\text { 3. In your opinion, which factors are more important to the patients about the hospital's food? } \\
\text { 4. What is your recommendation for the promotion of hospital's food quality? } \\
\text { 5. What is your recommendation for decreasing hospital's food wastes and increasing patients' } \\
\text { food intake in this hospital? }\end{array}$ \\
\hline Food providers & $\begin{array}{l}\text { Do you think which factors could affect the quality and quantity of hospital's food in this } \\
\text { hospital? } \\
\text { 2. In your opinion, which factors are of more importance for patients or they are paying more } \\
\text { attention to in this hospital? } \\
\text { 3. From your viewpoint, why do not some patients eat their entire food or do not eat hospital's } \\
\text { food at all in this hospital? } \\
\text { 4. From your viewpoint, which obstacles do exist to promote hospital's food quality in this } \\
\text { hospital? } \\
\text { what do you suggest to reduce the food wasted by patients or in hospital's kitchen in this } \\
\text { hospital? }\end{array}$ \\
\hline Patients & $\begin{array}{l}\text { 1. Do you consume all of the hospital's food? If not, why? } \\
\text { 2. What is your opinion about the quality of served foods/ snacks for patients in this hospital? } \\
\text { 3. What is your opinion about the quantity of served foods/ snacks for patients in this hospital? } \\
\text { 4. What is the most important factor in hospital's food for you? (e.g. taste, appearance, texture, } \\
\text { etc.) } \\
\text { 5. In your opinion, which effects have the quantity and type of food served by hospital on your } \\
\text { disease? (Is hospital's food in accordance with your disease? } \\
\text { 6. Do you think what should would we do to improve the quality of the hospital's food (and to } \\
\text { decrease food waste)? }\end{array}$ \\
\hline Hospital managers & $\begin{array}{l}\text { 1. What is your opinion about the quality of hospital's food in this hospital? } \\
\text { 2. What is your opinion about the quantity of hospital's food in this hospital? } \\
\text { 3. In your opinion, which items should be considered about the type, serving method, and totally } \\
\text { the quality of patient's food in this hospital? } \\
\text { 4. What is your recommendation for decreasing the hospital's food waste and improve the } \\
\text { patient's food intake in this hospital? (do you think how we can decline the amount of wasted } \\
\text { food? Please clarify.) }\end{array}$ \\
\hline $\begin{array}{l}\text { Food staff (preparing and serving } \\
\text { staff) }\end{array}$ & $\begin{array}{l}\text { 1. Do you think the amount of served foods is enough for patients? } \\
\text { 2. In your idea, which factors can improve the quality of patients' food in this hospital? } \\
\text { 3. Which items in food are more important to the patients in this hospital? (taste, texture, } \\
\text { temperature, etc.) } \\
\text { 4. How can we reduce the amount of food wastes by the patients in this hospital? } \\
\text { 5. From your viewpoint, which obstacles exist to promote the quality of hospital's food? }\end{array}$ \\
\hline
\end{tabular}

It is a "semi-structured" questionnaire, which means that the questions will not be asked necessarily in a specific order. The topic guide contains some core and probing questions about reasons for wasting plate-food by the patients. Depending on the question, some complementary questions may be asked. Clear words and neutral sentences will be used to make it understandable for interviewees, but to not affect their responses. There will be six target groups, including nurses, dieticians, food providers, patients, hospital managers and food staff. The topic guide developed based on the objectives of the study and target groups was piloted before starting the fieldwork. After the clarification of the objectives and procedure of the qualitative study for the participants, they will be allowed to read and sign the written consent. Each interview will last 30 to $60 \mathrm{~min}$ and will be held in a suitably calm place 
in the hospitals. The research team will consist of a facilitator and at least one note-taker. At the beginning of the interview, the facilitator will introduce herself and clarify the aim and procedure of the study. All the participants' answers and cues (body languages), in addition to date and place of the interview, will be recorded by the note-taker(s). To avoid missing any details, the interviews will be recorded using a voice-recorder simultaneously, with the participants' permission. The interviews will be continued until "data saturation", in which no novel responses will be given. At this point, the researcher will stop the interviews (55). A member of the research team qualified in qualitative studies as the observer will check some of the interviews by random. $\mathrm{He} /$ she will assess "quality assurance" through auditing the processes of interviewing, coding, analyzing and interpreting the data to control the reliability and validity of data. To ensure that the interviewer had an accurate understanding of the interviewee's responses, she will restate her perception of their answers during and at the end of the interview and will ask them to correct her perception if necessary (member check). Furthermore, validity of the data will be assured by asking same questions from various sources (triangulation) such as different groups of informants (i.e. patients, nurses, managers, nutritionists, food staff and food provider) and recording the tone of speaking, the exact statements and if possible any body movements.

\section{c. Qualitative data analysis}

In this study, the data will be collected, analyzed and classified, simultaneously. The approach of the study will be "content analysis" (56). To begin the analysis, all notes will be sent to MAXQDA software (Version 10, VERBI Software Consult. Sozialforschung GmbH, Berlin, Germany). To explore emerging themes and subthemes, the notes will be read several times carefully by the research team followed by organizing (coding) data based on the main objectives of the study. The percentage of agreements between coders will be reported using MAXQDA software. Also, the frequency of each theme will be determined and categories will be developed based on the most frequent themes. Finally, the research team will discuss the emerged themes and core categories and the main influencing factors affecting hospital food waste will be reported.

\section{Results}

The current study has been approved and funded in January 2020 by the Research Committee of National Nutrition and Food Technology Research Institute (NNFTRI), at Shahid Beheshti University of Medical Sciences. Due to the COVID-19 pandemic, we have recruited 34 participants at the submission time of the manuscript, no data analysis has been carried out and the authors expect to publish the results in autumn 2021.

\section{Discussion}

The primary objective of this study is to evaluate the nutritional status, quantity and cost of food wasted by hospitalized patients in medical and surgical wards. The secondary objective is to identify the main reasons for wasting food by the patients to suggest solutions to decrease the food waste.

The study has several strengths: A variety of biomarkers, regarding protein malnutrition, micronutrient deficiency, oxidative stress and inflammation, will be measured. In addition, malnutrition will be assessed in both subjective (using MNA and SGA tools) and objective forms (using biomarkers). Some studies have suggested an association between some serum biomarkers, such as albumin, PAB and retinol, with patient's nutritional status or recent dietary intake (57-59). Moreover, the amount and cost of food waste and its association with patients' nutritional status (due to inadequate intake) will be evaluated simultaneously, which will provide reliable data about the current situation in hospitals for health authorities and policymakers. In addition, the qualitative study will capture the other dimensions of food waste from the viewpoint of the patients and personnel engaged in the hospital's food chain, which will provide important information for understanding the actual reasons and proposing practical solutions.

The present study may encounter some limitations: Firstly, food intake will be recorded through a 24-h food recall due to the limited duration of hospitalization. While a single 24-h recall may not capture the entire intake of the patient, it can provide sufficient data to assess nutritional intake in a larger population (60). Moreover, since food recall is initially based on the memory and could miss some dietary data (61), meals and snacks will be weighed at the same time to provide a better estimation of the daily ingested food. Secondly, dinner food waste will not be measured due to technical issues including insufficient data collection at the time of serving and at the end of the meal and time restriction. However, food waste at dinner will be estimated by subtracting the consumed quantities (24-h recall) from the served quantities. Finally, micronutrient status will be assessed only for two vitamins (vitamins A and D) due to budget limitation. Serum $25(\mathrm{OH}) \mathrm{D}$ will be evaluated because of the high prevalence of its deficiency in the community (62) and the associated adverse clinical outcomes (63). Moreover, vitamin A will be assessed because of its axial role in immunocompetence and the possible link with malnutrition in hospitalized patients (64). 


\section{Acknowledgement}

Author Contributions: Conceptualization, T.R.N. and M.A.; methodology, T.A., M.A., R.A. and D.G.; funding acquisition, T.R.N.; validation, T.R.N. and M.A.; investigation, R.A.; software works, R.A. and B.N.; formal analysis, B.N.; project administration, P.T. and T.R.N.; the original draft preparation, R.A. and T.R.N; funding acquisition, T.R.N. All the authors will equally collaborate with developing approaches to diminish food waste in hospitals and with writing the article.

\section{Funding/Support}

This research is funded by the Research Committee of National Nutrition and Food Technology Research Institute (NNFTRI) at Shahid Beheshti University of Medical Sciences. The funding body had no intervention in designation, collection and analysis of the study, or in interpretation of data and writing the manuscript.

Institutional Review Board Statement: The study was conducted according to the guidelines of the Declaration of Helsinki, and approved by the Ethics Committee of National Nutrition and Food Technology Research Institute (NNFTRI) (ethical code: IR.SBMU.NNFTRI.REC. 1398.073; approval date: 2020-01-05).

Informed Consent Statement: Informed consent will be obtained from all subjects involved in the study.

Data Availability Statement: For supporting data Please contact the corresponding author.

\section{Financial disclosure}

The authors declare no conflict of interest. The funders had no role in the design of the study; in the collection, analyses, or interpretation of data; in the writing of the manuscript, or in the decision to publish the results.

\section{References}

1. Bauer J, Bannister M, Crowhurst R, Denmeade SL, Horsley P, Mcdonald C, et al. nutritionDay: An Australian hospital's participation in international benchmarking on malnutrition. Nutrition \& Dietetics. 2011;68(2):134-9.

2. Dupertuis Y, Kossovsky M, Kyle U, Raguso C, Genton L, Pichard C. Food intake in 1707 hospitalised patients: a prospective comprehensive hospital survey. Clinical Nutrition. 2003;22(2):115-23

3. Vesga AV, Gamboa ED. Risk of malnutrition associated with poor food intake, prolonged hospital stay and readmission in a high complexity hospital in Colombia. Nutricion hospitalaria. 2015;32(3):1308-14

4. Williams P, Walton K. Plate waste in hospitals and strategies for change. e-SPEN, the European e-Journal of Clinical Nutrition and Metabolism. 2011;6(6):e235-e41.

5. Agarwal E, Ferguson M, Banks M, Batterham M, Bauer J, Capra S, et al. Malnutrition and poor food intake are associated with prolonged hospital stay, frequent readmissions, and greater in-hospital mortality: results from the Nutrition Care Day Survey 2010. Clinical Nutrition. 2013;32(5):737-45

6. Hiesmayr M, Schindler K, Pernicka E, Schuh C, SchoenigerHekele A, Bauer P, et al. Decreased food intake is a risk factor for mortality in hospitalised patients: the NutritionDay survey 2006. Clinical nutrition. 2009;28(5):484-91.

7. Gout BS, Barker LA, Crowe TC. Malnutrition identification, diagnosis and dietetic referrals: are we doing a good enough job? Nutrition \& Dietetics. 2009;66(4):206-11.

8. Norman K, Pichard C, Lochs H, Pirlich M. Prognostic impact of disease-related malnutrition. Clinical nutrition. 2008;27(1):5-15.

9. Curtis LJ, Bernier P, Jeejeebhoy K, Allard J, Duerksen D, Gramlich L, et al. Costs of hospital malnutrition. Clinical Nutrition. 2017;36(5):1391-6.

10. Norouzy A, Hashemi P, Amiri A, Salehi M, Deldar K, Fakhar $\mathrm{Y}$, et al. Adult malnutrition screening, prevalence in four Iranian hospitals: cross-sectional study. Mediterranean Journal of Nutrition and Metabolism. 2012;5(1):45-8.

11. Nematy M, Salami H, Norouzy A, Siadat Z, Shahsavan N, Tavallaie $S$, et al. Indices of malnutrition in patients admitted to general medical and chest medicine wards of an Iranian teaching hospital on admission and discharge. Mediterranean Journal of Nutrition and Metabolism. 2013 April 01;6(1):537.

12. Simzari K, Vahabzadeh D, Saeidlou SN, Khoshbin S, Bektas Y. Food intake, plate waste and its association with malnutrition in hospitalized patients. Nutricion hospitalaria. 2017;34(6):1376-81.

13. Norouzy A. NUTRITIONAL STATUS IN HOSPITALIZED PATIENTS: RESULTS OF NATIONAL SURVEY FOR NUTRITIONAL ASSESSMENT IN IRANIAN HOSPITALS. The 3rd International and 15th Iranian Nutrition Congress; Tehran: Nutrition and Food Sciences Research 2018 Oct- Dec

14. van Bokhorst-de van der Schueren MA, Roosemalen MM, Weijs PJ, Langius JA. High waste contributes to low food intake in hospitalized patients. Nutrition in clinical practice. 2012;27(2):274-80.

15. Correia MIT, Hegazi RA, Higashiguchi T, Michel J-P, Reddy BR, Tappenden KA, et al. Evidence-based recommendations for addressing malnutrition in health care: an updated strategy from the feedM. E. Global Study Group. Journal of the American Medical Directors Association. 2014;15(8):544-50.

16. Lim SL, Ong KCB, Chan YH, Loke WC, Ferguson M, Daniels L. Malnutrition and its impact on cost of hospitalization, length of stay, readmission and 3-year mortality. Clinical Nutrition. 2012;31(3):345-50.

17. Correia MIT, Waitzberg DL. The impact of malnutrition on morbidity, mortality, length of hospital stay and costs evaluated through a multivariate model analysis. Clinical nutrition. 2003;22(3):235-9.

18. Gomes F, Baumgartner A, Bounoure L, Bally M, Deutz NE, Greenwald JL, et al. Association of nutritional support with clinical outcomes among medical inpatients who are malnourished or at nutritional risk: an updated systematic review and meta-analysis. JAMA network open. 2019;2(11):e1915138-e.

19. Dias-Ferreira C, Santos T, Oliveira V. Hospital food waste and environmental and economic indicators-a Portuguese case study. Waste management. 2015;46:146-54. 
20. Hong W, Kirk D. The analysis of edible plate waste results in 11 hospitals in the UK. Foodservice Research International. 1995;8(2):115-23.

21. Barton A, Beigg C, Macdonald I, Allison S. High food wastage and low nutritional intakes in hospital patients. Clinical Nutrition. 2000;19(6):445-9.

22. Taghipour H, Mosaferi M. Characterization of medical waste from hospitals in Tabriz, Iran. Science of the total environment. 2009;407(5):1527-35.

23. Ferdowsi A, Ferdosi M, Mehrani Z, Narenjkar P. Certain hospital waste management practices in Isfahan, Iran. International journal of preventive medicine. 2012;3(Suppl1):S176.

24. Bazrafshan E, Kord Mostafapoor F. Survey of medical waste characterization and management in Iran: a case study of Sistan and Baluchestan Province. Waste Management \& Research. 2011;29(4):442-50.

25. Monier V, Mudgal S, Escalon V, O'Connor C, Gibon T, Anderson G, et al. Preparatory study on food waste across EU 27. European Commission, Directorate-General for the Environment. 2010.

26. Abeliotis K, Lasaridi K, Costarelli V, Chroni C. The implications of food waste generation on climate change: The case of Greece. Sustainable production and consumption. 2015;3:8-14.

27. Jones NE, Suurdt J, Ouelette- Kuntz H, Heyland DK. Implementation of the Canadian Clinical Practice Guidelines for Nutrition Support: a multiple case study of barriers and enablers. Nutrition in clinical practice. 2007;22(4):449-57.

28. EPA. Food Waste in Irish Hospitals - Factsheet 2012.

29. Hajifathali A, Ainy E, Jafari H, Moghadam NM, Kohyar E, Hajikaram S. In-patient satisfaction and its related factors in Taleghani University Hospital, Tehran, Iran. Pakistan Journal of Medical Sciences. 2008;24(2):274.

30. Norouzy A. Nutritional status in hospitalized patients: Results of national survey for nutritional assessment in iranian hospitals. the 3rd International and 15th Iranian Nutrition Congress; Tehran, Iran. Tehran: Nutrition and Food Sciences Research; 2018-12-19

31. Faul F, Erdfelder E, Buchner A, Lang A-G. Statistical power analyses using $\mathrm{G}^{*}$ Power 3.1: Tests for correlation and regression analyses. Behavior research methods. 2009;41(4):1149-60.

32. Vandenbroucke JP, Von Elm E, Altman DG, Gøtzsche PC, Mulrow CD, Pocock SJ, et al. Strengthening the Reporting of Observational Studies in Epidemiology (STROBE): explanation and elaboration. PLoS Med. 2007;4(10):e297.

33. Jarzem P, Gledhill R. Predicting height from arm measurements. Journal of pediatric orthopedics. 1993;13(6):761-5.

34. Chumlea WC, Roche AF, Mukherjee D. Nutritional assessment of the elderly through anthropometry: Ross Laboratories; 1984.

35. Chumlea WC, Guo SS, Steinbaugh ML. Prediction of stature from knee height for black and white adults and children with application to mobility-impaired or handicapped persons. Journal of the American Dietetic Association. 1994;94(12):1385-91.
36. Nikooyeh B, Shariatzadeh N, Kalayi A, Zahedirad M, Neyestani T. Development of new predictive equations for basal metabolic rate in Iranian healthy adults: negligible effect of sex [in press]. International Journal of Vitamin and Nutrition Research. 2020.

37. Mifflin MD, St Jeor ST, Hill LA, Scott BJ, Daugherty SA, Koh YO. A new predictive equation for resting energy expenditure in healthy individuals. The American journal of clinical nutrition. 1990;51(2):241-7.

38. Long $\mathrm{C}$. The energy and protein requirements of the critically ill patient. Nutritional assessment. 1984:157-81.

39. Force CMT. Subjective Global Assessment Form 2017 [cited 2019. 21 Jan]. Available from: http://nutritioncareincanada.ca /sites/default/uploads/files/SGA\%20Tool\%20EN\%20BKWT_ 2017.pdf.

40. Institute NN. Mini Nutritional Assessment Vevey, Switzerland2009 [cited Feb 2019]. Available from: https://www.mna-lderly.com/forms/mini/mna_mini_farsi.pdf.

41. Bharadwaj S, Ginoya S, Tandon P, Gohel TD, Guirguis J, Vallabh $\mathrm{H}$, et al. Malnutrition: laboratory markers vs nutritional assessment. Gastroenterology report. 2016;4(4):272-80.

42. Talwar D, Ha TK, Cooney J, Brownlee C, St JO'Reilly D. A routine method for the simultaneous measurement of retinol, $\alpha$-tocopherol and five carotenoids in human plasma by reverse phase HPLC. Clinica Chimica Acta. 1998;270(2):85-100.

43. Doustmohammadian A, Amini M, Esmaillzadeh A, Omidvar N, Abtahi M, Dadkhah-Piraghaj $\mathrm{M}$, et al. Validity and reliability of a dish-based semi-quantitative food frequency questionnaire for assessment of energy and nutrient intake among Iranian adults. BMC research notes. 2020;13(1):1-7.

44. Joint W, Organization WH, editors. Vitamin A deficiency and xerophthalmia: report of a Joint WHO/USAID Meeting [held in Jakarta from 25 to 29 November 1974]. Vitamin A deficiency and xerophthalmia: report of a Joint WHO/USAID Meeting [held in Jakarta from 25 to 29 November 1974]; 1976.

45. Underwood BA. Methods for assessment of vitamin A status. The Journal of nutrition. 1990;120(suppl_11):1459-63.

46. Olson JA. Vitamin A, retinoids and carotenoids. Modern nutrition in health and disease. 1994;1:287-307.

47. Neyestani T, Gharavi A. Simultaneous determination of lycopene and beta-carotene with high-performance liquid chromatography. Iranian Journal of Nutrition Sciences \& Food Technology. 2007;1(3):45-50. eng.

48. Thacher TD, Clarke BL, editors. Vitamin D insufficiency. Mayo Clinic Proceedings; 2011: Elsevier.

49. Kei S. Serum lipid peroxide in cerebrovascular disorders determined by a new colorimetric method. Clinica chimica acta. 1978;90(1):37-43.

50. Neyestani T, Shariatzadeh N, Gharavi A, Kalayi A, Khalaji N. Physiological dose of lycopene suppressed oxidative stress and enhanced serum levels of immunoglobulin $\mathrm{M}$ in patients with Type 2 diabetes mellitus: a possible role in the prevention of long-term complications. Journal of endocrinological investigation. 2007;30(10):833-8.

51. Neyestani TR, Fereydouni Z, Hejazi S, Salehi-Nasab F, Nateghifard F, Maddah M, et al. Vitamin C status in Iranian children with acute lymphoblastic leukemia: evidence for 
increased utilization. Journal of pediatric gastroenterology and nutrition. 2007;45(1):141-4.

52. Nehring S, Goyal A, Bansal P, Patel B. C Reactive Protein (CRP) [Updated 2020 Mar 13]. In: StatPearls [Internet]. Treasure Island (FL): StatPearls Publishing; Available from: https://www.ncbi.nlm.nih.gov/books/NBK441843/. 2020.

53. Busher J. Serum Albumin and Globulin. . In: Walker H, Hall W, Hurst J, editors. Clinical Methods: The History, Physical, and Laboratory Examinations (Available from: https://wwwncbinlmnihgov/books/NBK204/)1990.

54. Kuszajewski M, Clontz A. Prealbumin is best for nutritional monitoring. Nursing2020. 2005;35(5):70-1.

55. Long T, Johnson M. Rigour, reliability and validity in qualitative research. Clinical effectiveness in nursing. 2000;4(1):30-7.

56. Vaismoradi M, Turunen H, Bondas T. Content analysis and thematic analysis: Implications for conducting a qualitative descriptive study. Nursing \& health sciences. 2013;15(3):398405 .

57. Grass F, Bertrand P, Schäfer M, Ballabeni P, Cerantola Y, Demartines N, et al. Compliance with preoperative oral nutritional supplements in patients at nutritional risk- only a question of will? European journal of clinical nutrition. 2015;69(4):525.
58. Mahan LK, Raymond JL. Clinical: Biochemical, Physical, and Functional Assessment. Krause's food \& the nutrition care process. Fourteenth ed: Elsevier; 2017. p. 107.

59. Benjamin DR. Laboratory tests and nutritional assessment: Protein-energy status. Pediatric Clinics of North America. 1989;36(1):139-61.

60. Biro G, Hulshof K, Ovesen L, Cruz JA. Selection of methodology to assess food intake. European journal of clinical nutrition. 2002;56(2):S25-S32.

61. Block G. A review of validations of dietary assessment methods. American journal of epidemiology. 1982;115(4):492-505.

62. Nikooyeh B, Abdollahi Z, Hajifaraji M, Alavi-majd H, Salehi F, Yarparvar AH, et al. Vitamin D status and cardiometabolic risk factors across latitudinal gradient in Iranian adults: National food and nutrition surveillance. Nutrition and health. 2017;23(2):87-94.

63. Botros RM, AbdElsalam Besibes MM, Bahaaeldin AM, Abo Elyazed S. Vitamin d status in hospitalized chronically ill patients. Journal of the American College of Nutrition. 2018;37(7):578-82.

64. Huang Z, Liu Y, Qi G, Brand D, Zheng SG. Role of vitamin $A$ in the immune system. Journal of clinical medicine. 2018;7(9):258. 